\title{
Utilization of MOSFET transistor as an electronic load to trace I-V and P-V curve of a solar panel
}

\author{
Abdellah Asbayou ${ }^{1 *}$, Mohamed Agdam ${ }^{1}$, Amine Aamoume ${ }^{1}$, Ahmed Soussi ${ }^{1}$, Ahmed Ihla', \\ Lahoussine Bouhouch ${ }^{2}$ \\ ${ }^{1}$ Laboratory of Materials and Renewable Energies, University Ibn Zohr, 80000 Agadir, Morocco \\ ${ }^{2}$ ESTA Ibn ZohrUniversity, BP 33/S, 80000 Agadir, Morocco.
}

\begin{abstract}
To understand the electrical behavior of a photovoltaic panel, it is necessary to know the characteristic $I_{p v}=f\left(V_{p v}\right)$. The best way to obtainthis I-V curve is to use a variable resistor.

This paper proposes a new and simple technique based on a MOSFET transistor as a variable load, which whose gate voltage is controlled by an $\mathrm{RC}$ filter from the Arduino. A comparison under standard temperature and illumination conditions between the manufacturer's datasheet with the simulation by MATLAB/Simulink on the one hand, and on the other hand between the manufacturer's datasheet with the experimental data for the evaluation of this technique that has been performed.
\end{abstract}

\section{Nomenclature}

$a_{0} \quad$ Temperature correction coefficient for current $\left({ }^{\circ} \mathrm{C}^{-1}\right)$.

$b_{0} \quad$ Temperature correction coefficient for voltage $\left({ }^{\circ} \mathrm{C}^{-1}\right)$.

$G \quad$ Solar irradiance on module plane $\left(\mathrm{W} / \mathrm{m}^{2}\right)$.

$I_{p h} \quad$ Photo-generated current (A).

Ipv Solar cell terminal current (A).

$I_{S C} \quad$ Short circuit current (A).

$I_{0} \quad$ Reverse saturation current (A).

$I_{0 i} \quad$ Reverse saturation current of diode in conventional model (A).

$n_{1} \quad$ First diode ideality factor

$N_{S} \quad$ Cells number connected in series.

$N_{s h} \quad$ Cells number connected in shunt.

PV Photovoltaic.

$R_{S} \quad$ Series resistance (W).

$R_{\text {sh }} \quad$ Shunt resistance (W).

STC Standard Test Conditions $\left(G_{0}=1000 \mathrm{~W} / \mathrm{m}^{2}, T_{0}=25{ }^{\circ}\right.$ Cand $\left.A M=1.5\right)$.

$T \quad$ Cell or Module operating temperature $\left({ }^{\circ} \mathrm{C}\right)$.

$T_{\mathrm{a}} \quad$ Ambient temperature $\left({ }^{\circ} \mathrm{C}\right)$.

$\Delta T \quad$ Temperaturedifference $:=T-T_{0}\left({ }^{\circ} \mathrm{C}\right)$.

$V_{O C} \quad$ Solar cell open-circuit voltage (V).

$V_{p v} \quad$ Solar cell output voltage (V).

* Corresponding author:a.asbayou@gmail.com 


\section{Introduction}

There is a lot of research on the measurement of the $I-V$ characteristic of PV modules under different operating conditions with a variety of methods [1].The most and easy one is by using a variable resistor in series with the PV generator as a load.

Another way to plot the $I-V$ curve of a PV generator, is the capacitive load. Some authors [2-4] have used capacitors as an automatic variable load to change the voltage $V_{p v}$ and the current $I_{p v}$ during the capacitor charging operation, which allowed them to obtain the $I-V$ characteristic of the PV generator.

Kuai and al.[5] proposed a device based on an electronically variable load using the APL501J MOSFET transistor, which covers the full range of the $I-V$ characteristic of PV panels in a very short time.

This paper proposes the design of a bench for tracing the $I-V$ and $P-V$ characteristics of PV panels based on a MOSFET(IRF740) transistor controlled by Arduino via a DC signal, which is injected into a simple $R C$ filter to vary the $V_{G S}$ control voltage in a progressive way (figure 1). The system is analyzed and experimentally tested under standard temperature and lighting conditions using an SX330J solar panel.

This paper is divided into 5 sections: The first one gives the introduction of methods used to obtain the $I-V$ characteristic of a PV panel. Then in section 2, we expose a brief description of the MOSFET by presenting the electrical behavior $I_{D}=f\left(V_{D S}, V_{G S}\right)$. Then, section 3 gives details on the measurement bench, and section 4 summarizes and discusses the results obtained. We will conclude this article with a conclusion and the perspectives of this work.

\section{Theoretical background of MOSFET as an electronic load}

The MOSFET is a device that function as an electronically controlled load that change the operating point of a PV generator over the full range of the $I-V$ characteristic [6]. When a control voltage is applied to its grid, it generates a fast and variable PV output current from 0 to $I_{s c}(A)$, and a variable output voltage from $V_{o c}$ to $0(\mathrm{~V})$.

The speed of the scan is made as fast as possible to reduce the effect of variation in illuminance and temperature fluctuations caused by cloud movement or other weather changes [7]. In this way, all points drawn on the $I-V$ curve are captured under the same weather conditions in a very short time. The fast scanning also protects the MOSFET from superheating [8]. Figure 1 shows the variations of the $\mathrm{I}_{D}$ current as a function of the $\mathrm{V}_{D S}$ voltage and the value of the control voltage $\mathrm{V}_{G S}$.

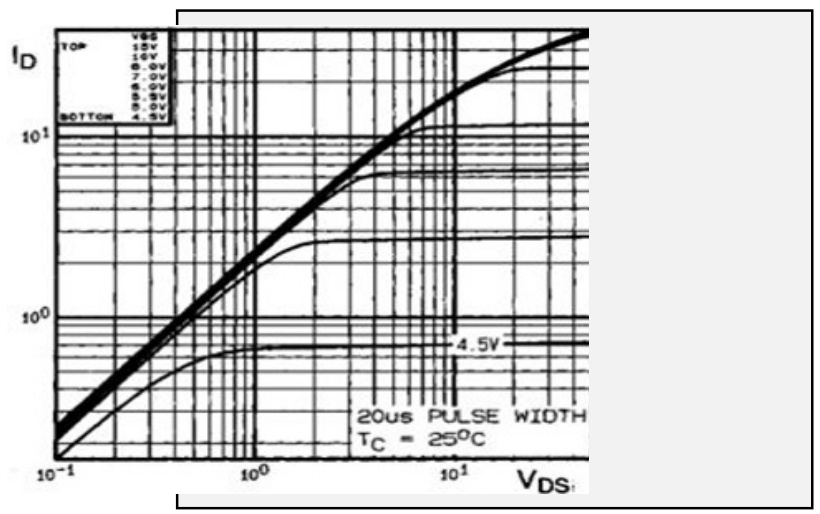


Fig. 1.Characteristicsof (IRF740) MOSFET, at $25^{\circ} \mathrm{C}$ [9]

The three operating regimes of the MOSFET that describe the relationship between $I_{D}$ as a function of $\mathrm{V}_{\mathrm{GS}}$ and $\mathrm{V}_{\mathrm{DS}}$ are [5]:

Blocking mode if $: V_{G S}<V_{t h}$, So $I_{D}=0 A_{(1)}$

Ohmic mode if:

$$
\begin{aligned}
& V_{G S}-V_{t h}>0 \& V_{G S}-V_{t h}>V_{D S} S o: \\
& I_{D}=K\left[2\left(V_{G S}-V_{t h}\right) V_{D S}-V_{D S}^{2}\right]_{(2)}
\end{aligned}
$$

Saturation mode if:

$$
\begin{aligned}
& V_{G S}-V_{t h}>0 \& V_{G S}-V_{t h}<V_{D S} S o: \\
& I_{D}=K\left(V_{G S}-V_{t h}\right)^{2}(3)
\end{aligned}
$$

Where $K$ is the constant of the device and $V_{t h}$ is the transistor control threshold voltage.

By changing the value of $V_{G S}$ in an appropriate range, the measurement points can scan between $I_{S C}$ and $V_{O C}$. According to Figure 2:

$$
I_{D}=I_{p v} \text { which } I_{p v}=I_{p h}-I_{d 1}-I_{s h}(4)
$$

$I_{p v}$ The electrical current of the PV panel according to the 1-diode model (Figure 2),

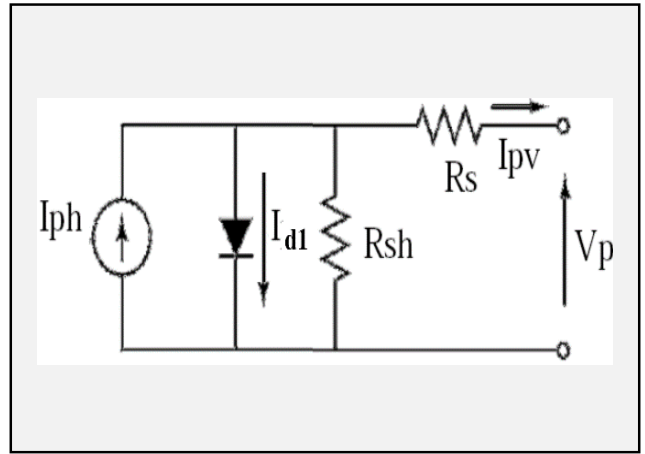

Fig. 2. Equivalent circuit of a PV cell with 1 diode

The photo-current $I_{p h}$ depends linearly on solar radiation, but also influenced by temperature, depending on the following relationship[10]:

$$
I_{p h}=\left(I_{p h, r e f}+\alpha_{0} \cdot \Delta T\right) \frac{G}{G_{\text {ref }}}(5)
$$

In the STC (Standard Test Conditions) $\left(G_{r e f}=1000 \mathrm{~W} / \mathrm{m}^{2}, T_{r e f}=298 \mathrm{~K}\right)$, the expression of $I_{p h, r e f}$ is given by:

Therefore:

$$
I_{p h, \text { ref }}=\left(1+\frac{R_{S}}{R_{s h}}\right) I_{s c, r e f(6)}
$$

$$
I_{p h}=\left(\left(1+\frac{R_{s}}{R_{s h}}\right) I_{s c, r e f}+\alpha_{0} \Delta T\right) \frac{G}{G_{r e f}}(7)
$$

By application of the mesh law, the $I_{s h}$ current in the shunt resistor is expressed by:

$$
I_{s h}=\frac{V_{p v}+R_{S} I_{p v}}{R_{S h}}(8)
$$

The diode current $I_{d i}$ is given by

With

$$
I_{d 1}=I_{01}\left[\exp \left(\frac{V_{p v}+R_{s} I_{p v}}{n_{1} V_{t h}}\right)-1\right]_{(9)}
$$


$I_{01}=\frac{I_{s c, r e f}+a_{0} \Delta T}{\exp \left(\frac{V_{0 c, r e f}+\beta_{0} \Delta T}{V_{t h}}\right)-1}(10)$

And: $V_{t h}=\frac{k T}{q}$ is the thermal voltage of the module.

$I_{01}$ are the saturation current of the one diode.

$n_{1}$ are the ideality factors.

So, the current supplied by the solar cell in 1 diode model is given by the following relation $[11]$ :

$I_{p v}=I_{p h}-I_{01}\left[\exp \left(\frac{V_{p v}+R_{S} I_{p v}}{n_{1} V_{t h}}\right)-1\right]-\frac{V_{p v}+R_{s} I_{p v}}{R_{S h}}(11)$

\section{Materials and methods}

A basic circuit with a MOSFET as electronic charge is shown in Figure 3

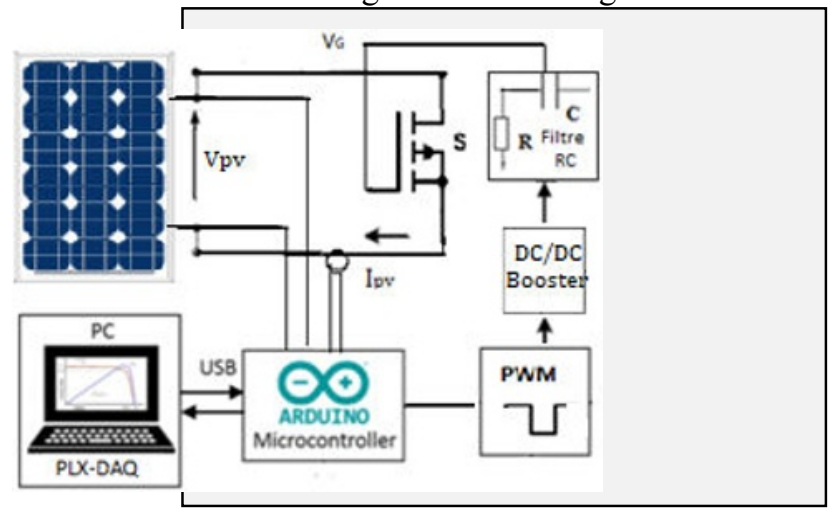

Fig. 3. Block diagram of circuit setup.

Arduino generates a continuous signal through pin3, then this signal is injected to an $R C$ filter, to vary the control voltage of the $V_{G S}$ MOSFET in a progressive way, which also requires the $R_{D S}$ resistor to change progressively (figure 1 ).

The proposed test bench for real-time characterization of the PV panel is realized using an Arduino UNO board as a data acquisition control, and transfer unit $\left(I_{P V}\right.$ and $\left.V_{P V}\right)$ to a computer via the PLX-DAQ tool [12].

The values of current intensity $I_{p v}$ and voltage $V_{p v}$ of the PV panel are measured using Arduino compatible current and voltage sensors, the temperature of the PV panel is measured using a thermocouple, while the irradiance is evaluated by using the FI 109SM Solar Meter [13], the panel used in this characterization is of polycrystalline type SX 330J, the electrical characteristics of which are summarized in Tables 1.

Table 1. Electrical characteristics of the PV panel SX 330J at STC $\left(1000 \mathrm{~W} / \mathrm{m}^{2}\right.$ and $\left.25^{\circ} \mathrm{C}\right)[14]$

\begin{tabular}{|c|c|c|}
\hline & Symbol & Value \\
\hline Maximum power & $P_{\max }$ & $30 \mathrm{~W}$ \\
\hline Voltage at $\mathrm{P}_{\max }$ & $V_{m p}$ & $16.8 \mathrm{~V}$ \\
\hline Current at $\mathrm{P}_{\max }$ & $I_{m p}$ & $1.78 \mathrm{~A}$ \\
\hline
\end{tabular}




\begin{tabular}{|c|c|c|}
\hline $\begin{array}{c}\text { Warranted minimum } \\
\mathrm{P}_{\max }\end{array}$ & -- & $27 \mathrm{~W}$ \\
\hline Short-circuit current & $I_{s c}$ & $1.94 \mathrm{~A}$ \\
\hline Open-circuit voltage & $V_{o c}$ & $21.0 \mathrm{~V}$ \\
\hline
\end{tabular}

Arduino $U N O$, is an open source microcontroller, used to manufacture $P W M$ control.Pulse Width Modulation $(P W M)$ is a technique used to control an analog circuit via the digital output, using two functions, either analogWrite or digitalWrite. A PWM (Pulse Width Modulation) signal is an electrical voltage with a maximum amplitude of $5 \mathrm{~V}$, a variable duty cycle and a constant frequency [15].

In this circuit (Figure 3), the signal delivered to control the MOSFET(IRF740) is amplified by a DC/DC booster, shown in Figure 4.

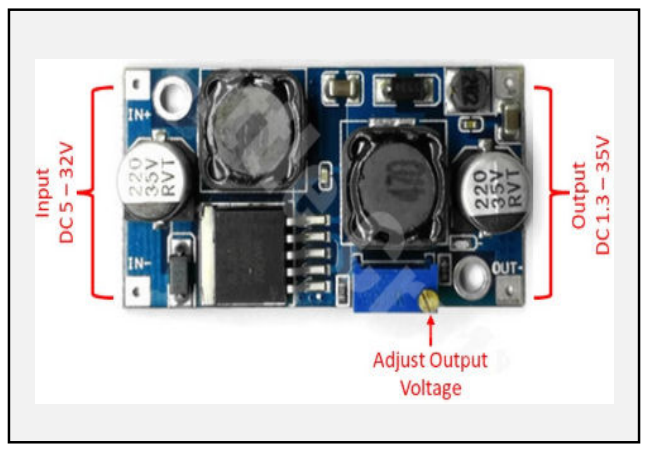

Fig. 4. XL6009E1 Typical Application Circuit (DC/DC Boost Converter) [16]

The signal at the output of DC/DC Boost Converter, is injected into a $R C$ filter, which $R=110 \pm 5.5 \Omega$ [17], and capacitor $C=4.7 \pm 0.94 \mathrm{mF}$ [17], connected in series to change the control of the MOSFET, and finally plotted the $I-V$ and $P-V$ characteristic of the solar panel.

According to Figure 5, the expression of the $V_{G S}(t)$ command voltage of MOSFET is given by:

$$
V_{G S}(t)=V_{P W M} \cdot\left(1-e^{-\frac{t}{R C}}\right)_{(12)}
$$

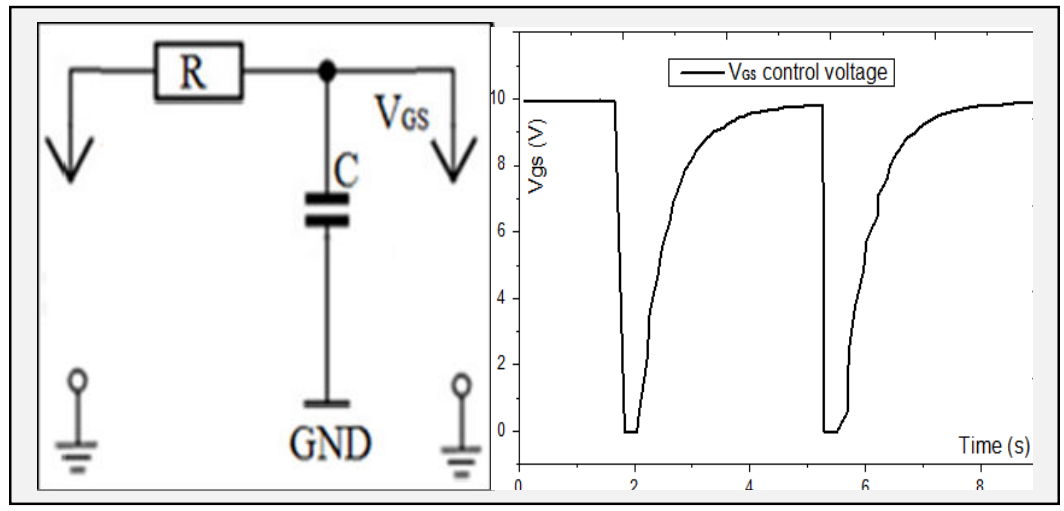

Fig. 5. Filter Flow Chart and $V_{D S}$ control voltage variation with time 
So according to the figure we can notice that the control voltage varies progressively, up to the value $10 \mathrm{~V}$, which leads to the variation of the resistor $\mathrm{R}_{\mathrm{DS}}$ of the MOSFETalso in a progressive way.

\section{Results and discussion}

\subsection{Variation of the $I_{p v}$ and $V_{p v}$ curve with time}

The precision of the $I-V$ curve in comparison to the datasheet depends strongly on the control voltage $\mathrm{V}_{\mathrm{GS}}$ which also depends on the resistance and capacitor in the control circuit, the following figures show the variation of the plotting time as a function of the values of the $R$ and $C$ components of the control circuit

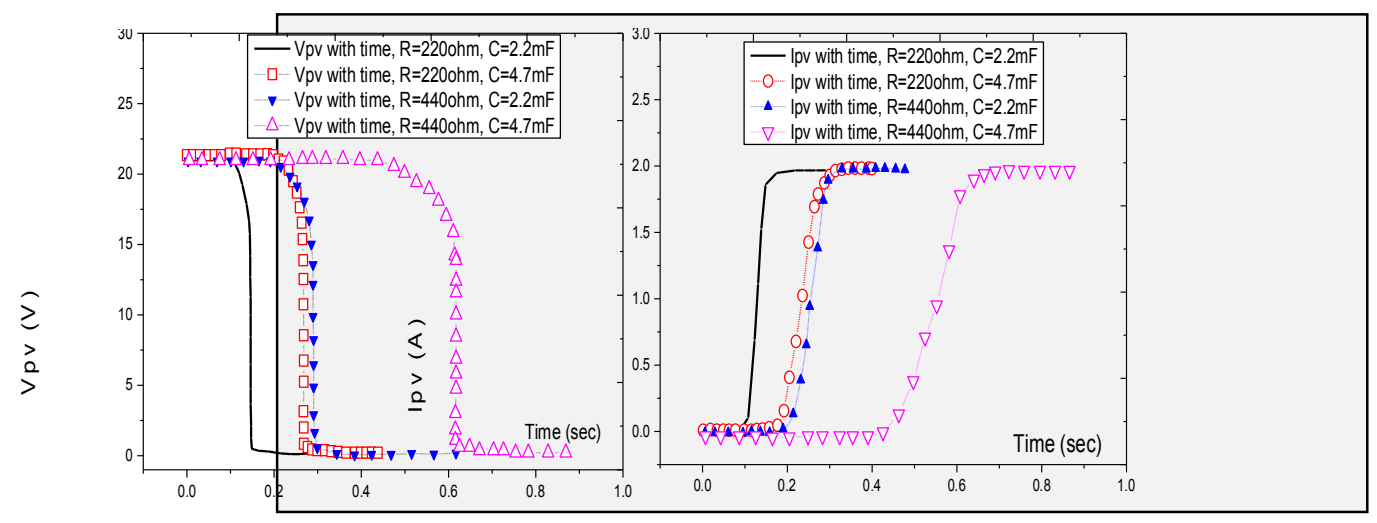

Fig. 6. $I_{p v}$ and $V_{p v}$ with time at $25^{\circ} \mathrm{C}$ and $\mathrm{G}=1000 \mathrm{~W} / \mathrm{m}^{2}$

In this manipulation the signal delivered by Arduino with duty cycle $\alpha=100 \%$, we can observe that for high $\mathrm{R}$ and $\mathrm{C}$ values the time required to plot the $\mathrm{I}-\mathrm{V}$ characteristic increases, for $\mathrm{R}=220$ 列 $\mathrm{C}=2.2 \mathrm{mF}$ the time of the trace is $0.18 \mathrm{sec}$, while $\mathrm{R}=440 \Omega$ and $\mathrm{C}=4.7 \mathrm{mF}$ tracing time is $0.69 \mathrm{sec}$, but on the other hand when $\mathrm{R}$ and $\mathrm{C}$ increases the number of points displayed by the Macro-Excel PLX-DAQ increases.

\subsection{I-V and $P-V$ characteristics of the PV module}

Using the electronic circuit described in Section 3 (Figure 3), the $I-V$ and $P$-Vcurves were traced for the SX 330J polysilicon solar panel, a comparison between the datasheet of the manufacturer's with the simulation by MATLAB/Simulink on the one hand was made, and on the other hand between the datasheet of the manufacturer's with the experimental data. 
4.2.1 I-V and P-V characteristics of the SX330J module at $25^{\circ} \mathrm{C}$ and $\mathrm{G}=1000 \mathrm{~W} / \mathrm{m}^{2}$

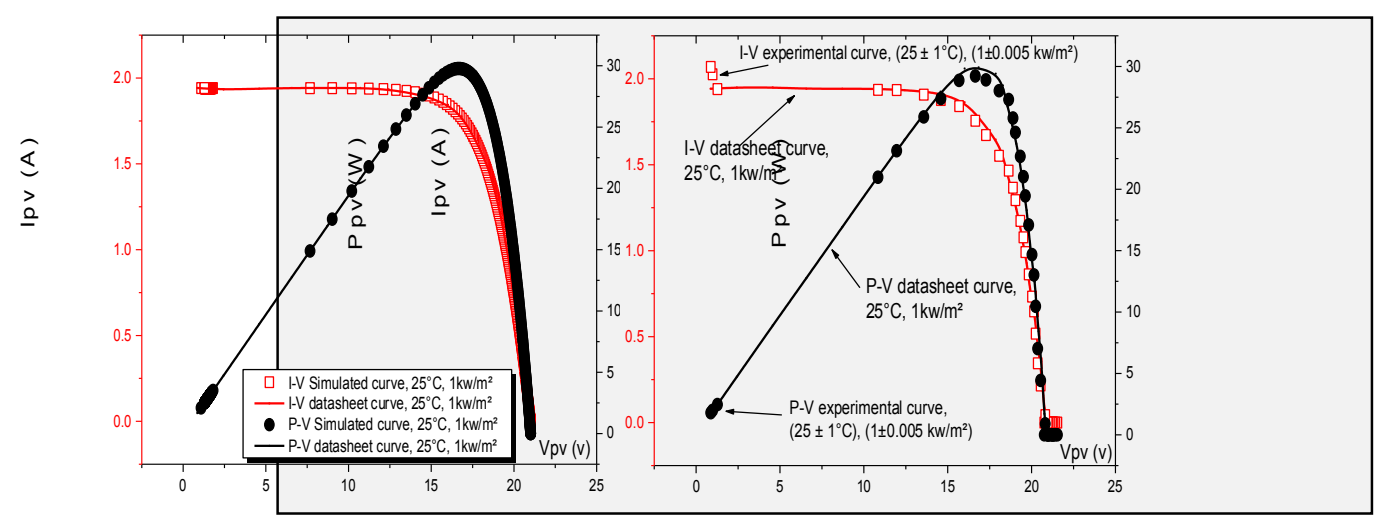

Fig. 7.I- $V$ and $P-V$ characteristics of the SX $330 \mathrm{~J}$ module at $25^{\circ} \mathrm{C}$ and $\mathrm{G}=1000 \mathrm{~W} / \mathrm{m}^{2}$

\subsubsection{I-V and P-V characteristics of the SX330J module at $50^{\circ} \mathrm{C}$ and $\mathrm{G}=1000 \mathrm{~W} / \mathrm{m}^{2}$}

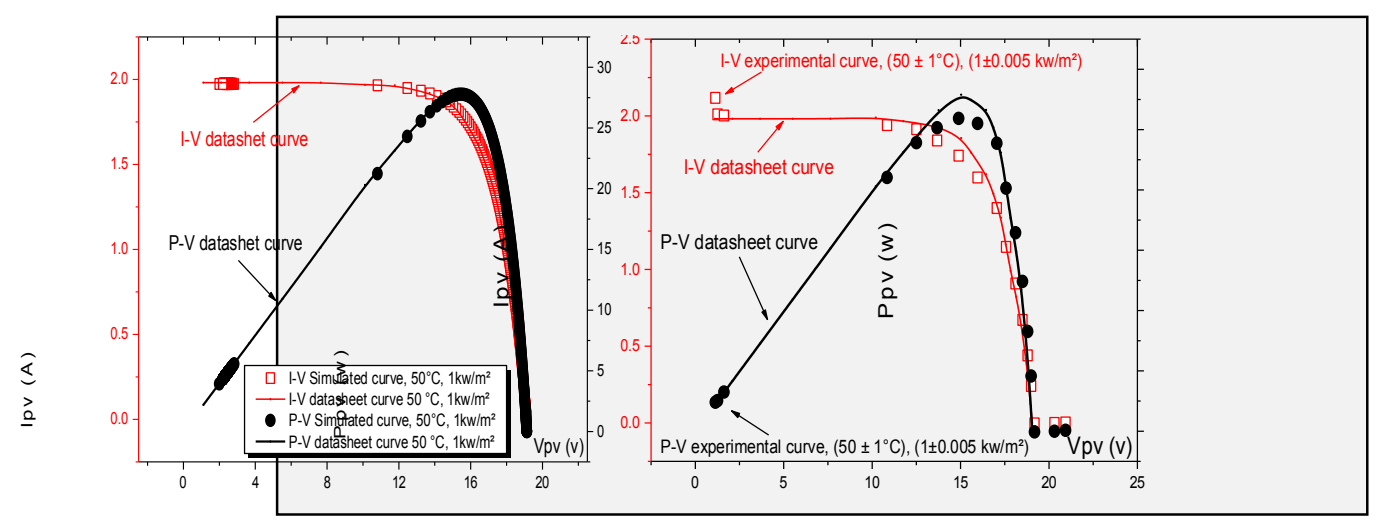

Fig. 8. $I-V \& P-V$ characteristics of the $\mathrm{SX} 330 \mathrm{~J}$ module at $50{ }^{\circ} \mathrm{C}$ and $\mathrm{G}=1000 \mathrm{~W} / \mathrm{m}^{2}$

The small deviation observed between the experimental results and the datasheet of the SX 330J polycrystalline panel is caused by several factors; such as the fluctuations of the illuminance $\mathrm{G}$, of the resistor $\mathrm{R}$ with temperature variations but also, the effect of the ohmic contacts between the cells of the PV panel and the rest of the mounting circuit.

\section{Conclusion and perspectives}

In this paper, we have proposed and realized a simple low-cost instrumentation solution to provide the I-V and P-V characteristics of the PV panel based on a MOSFET(IRF740) transistor controlled by Arduino via a DC signal. The whole system is composed of simple components, less complicated, less expensive and above all widely used in laboratories. The acquisition is realized through low-cost current and voltage sensors in communication with an Arduino type electronic board. The data is then reported in the Excel spreadsheet in real time using the Macro-Excel PLX-DAQ Spreadsheet interface. Experimental tests on a PV module type SX330J were performed under real operating conditions. The experimental results agree with the theoretical analysis carried out for the development of this 
methodology. The proposed circuit is suitable for future use to analyze the influence of real operating conditions, such as temperature, illumination, dust Shading effect and real-time observation of the PV module performance.

\section{References}

1. Zhu, Y., \& Xiao, W, J.Sol.Energy, 196, pp 346-357. (2020)

2. F. Spertino, J. Ahmad, A. Ciocia, P. Di, A. F. Murtaza, M. Chiaberge, J. Sol. Energy, 119, pp. 461-473, (2015).

3. D. T. Cotfas, P. A. Cotfas, D. Ursutiu, C. Samoila, "Current-Voltage Characteristic Raising Techniques for Solar Cells. Comparisons and Applications", 12th International Conference on Optimization of Electrical and Electronic Equipment, Romania, 20-22 May, pp. 1115-1120, (2010).

4. Z. Chen, W. Lin, L. Wu, C. Long, P. Lin, S. Cheng, Energy Procedia, 145, pp. 381387, (2018).

5. Y. Kuai, S. Yuvarajan, .J. Power Sources, 154(1), pp. 308-313, (2006).

6. Sarikh, S., Raoufi, M., Bennouna, A., Benlarabi, A., \&Ikken, B. "Design of an I-V Characteristic Tracer for Photovoltaic Systems". InInternational Renewable and Sustainable Energy Conference (IRSEC). Tanger Morocco, December 4-7, (2017)

7. Papageorgasa, P., Piromalis, D., Valavanisa, T., Kambasisa, S., Iliopouloua, T., Vokasa, G., "A low-cost and fast PV I-V curve tracer based on an open source platform with M2M communication capabilities for preventive monitoring". In International Conference on Technologies and Materials for Renewable Energy, Environment and Sustainability. TMREES15. Energy Procedia, (74), pp. 423-438, (2015).

8. Durán, E., Piliougine, M., Sidrach-de-Cardona, M., Galán, J., Andújar, J.M., "Different methods to obtain the I-V curve of PV modules: a review.", in Proceedings of the 33rd IEEE Photovoltaic Specialists Conference (PVSC '08), San Diego, Calif., USA, (2008).

9. International IOR rectifier MOSFET IRF740 datasheet catalog, Available online:http://www.datasheetcatalog.com/datasheets_pdf/I/R/F/7/IRF740.shtml, pp 251-256. (2020)

10. S. M. Hassan Hosseini, A.A Keymanesh, Sol. Energy, 137, pp. 594-607, (2016).

11. K. Ishaque, Zainal Salam, Hamed Taheri, Sol. Energy Mater. Sol. Cells, 95, pp. 586594, (2011).

12. Nichols, D. Phys. Teach, 55(4), 226-227 (2017).

13. Datasheet Solarimeter FI 109SM,Available online: https://www.distrame.fr/fr/website/Resultat-de-recherche-avecInstantSearch, 839332.html? q=FI+109SM\&submit=, (2020).

14. A.Tihane, M. Boulaid, L. Boughamrane, M. Nya, A. Ihlal , " Experimental analysis and Modeling of Performances of Silicon Photovoltaic Modules under the Climatic Conditions of Agadir" IOSR Journal of Electrical and Electronics Engineering, 12( 5), PP 42-46, Sep. - Oct. (2017).

15. Jo, S.-A., Lee, C.-H., Kim, M.-J., Ferracane, J., \& Lee, I.-B. Dent. Mater J. (2019).

16. XL6009E1 Adjustable DC-DC Boost Converter Module Datasheet web site https://www.addicore.com/XL6009E1-Boost-Converter-p/ad456.htm, (2020)

17. Datasheet, résistance et capacité,Available online : http://www.e44.com/ composants/composants-passifs/resistances/, (2020) 